\title{
The Risk Management of Gold Pawn Product in Bank Syariah Indonesia (BSI) Krian Branch
}

\author{
Ardhi Seiva Ahmad ${ }^{1 *}$, Ahmad Khoirur Rohim ${ }^{1}$, Muhammad \\ Arif Billah $^{1}$, Achmad Room Fitrianto ${ }^{1}$ \\ ${ }^{1}$ Faculty of Economics and Islamic Business, Sunan Ampel State \\ Islamic University, Jawa Timur, Indonesia \\ *Corresponding author: seivanakarjog@gmail.com
}

\author{
Article history \\ Received, 08 Sept 2021 \\ Revised 1, 22 Octo 2021 \\ Revised 2, 03 Nov 2021 \\ Accepted, 14 Dec 2021
}

\begin{abstract}
The purpose of this research is to analyze the risk management of the BSI gold pawn product in the BSI Krian branch. This research is a qualitative research. In this research, the official of BSI Krian branch served as key informants which have a adequate knowledge about financing process BSI gold pawn. Data collection conducted through interview, documentation, and observation techniques. The result of this research shows that BSI Krian branch implements risk management on the BSI gold pawn product. There are four steps in the process of implementing risk management on the gold pawn product BSI Krian branch; risk identification, risk measurement, risk monitoring, and risk control. Besides implement risk management BSI Krian branch has prepared risk mitigation on the gold pawn product. The mitigation processes are to mitigate the miss gold estimation accuracy, the gold storage risk, the risk of payment failure or jamming, the last but not least is mitigate the gold price drop. In the implementation of risk management and risk mitigation by BSI Krian Branch there are two obstacles those are from internal and external banks. In the effort to face that obstacles, BSI Krian branch has had an effort to overcome both from internal and external banks. With the implementation of risk management on the gold pawn product by BSI Krian branch can prevent and minimize the risk which arise from that financing.
\end{abstract}

Keyword: Risk Management, BSI Pawn Gold, BSI KCP Krian

Cite this article:

Ahmad, A.S., Rohim, A.K., Billah, M.A., Fitrianto, A.R., (2021).

The Risk Management of Gold Pawn Product in Bank Syariah Indonesia (BSI) Krian Branch, Jurnal Al-Qardh, 6(2), 49-61. https://doi.org/10.23971/jaq.v6i2.3537

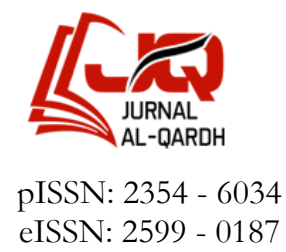

\section{Pendahuluan}

Perkembangan lembaga keuangan syariah di Indonesia semakin menunjukan kemajuannya, hal tersebut ditunjukkan dengan semakin banyaknya lembaga keuangan baik bank maupun non-bank yang berjalan dengan sistem Syariah. Seiring dengan perkembangan keuangan syariah perlu juga diiringi dengan perkembangan produk-produk syariah guna menunjang dalam operasional kegiatannya. Bank Syariah Indonesia (BSI) sebagai salah satu dari bank syariah memberikan beragam produk yang memudahkan nasabah dalam melakukan pembiayaan. Salah satu dari produk pembiayaan yang ditawarkan BSI adalah produk BSI gadai emas. BSI gadai emas adalah suatu produk pembiayaan yang dikeluarkan 
oleh BSI sebagai salah satu alternatif untuk memperoleh uang tunai secara cepat dengan dasar jaminan berupa emas. Pelaksanaan gadai juga pernah dilakukan oleh Rosulullah SAW seperti yang diceritakan oleh Ummul mukminin Aisyah R.A bahwa Rasulullah SAW pernah membeli makanan dari orang yahudi dengan cara berhutang dan menyerahkan baju besinya sebagai jaminan atas utang yang beliau lakukan. Gadai memiliki nilai sosial sangat tinggi serta dilakukan secara sukarela dengan dasar tolong menolong. Akan tetapi dalam praktek pelaksanaanya sekarang ini, ketika menjalankan transaksi gadai, kita memberikan barang yang kita punya (emas) untuk memperoleh pinjaman dana, dengan dasar pinjaman tersebut kita dibebankan biaya sampai waktu kita sanggup melunasi pinjaman tersebut. ${ }^{1}$ Meskipun memiliki perbedaan pelaksanaan antara zaman rasulullah SAW dengan sekarang. Hal tersebut tidak menurunkan minat masyarakat untuk menggadaikan barangnya baik itu di perbankan ataupun Lembaga keuangan. Transaksi gadai juga dijelaskan dalam Q.S. Al-baqarah: 283 yang berbunyi: "Jika kamu dalam perjalanan (dan bermuamalah secara tidak tunai) sedang kamu tidak memperoleh seorang penulis, maka hendaklah ada baranag tanggungan yang dipegang (oleh yang menghutangkan), akan tetapi jika Sebagian kamu mempercayai sebagaian yang lain, maka hendaklah yang dipercayai itu menunaikan amanat (hutang) ia dan hendaklah dia bertaqwa kepada Allah Tuhanyya....."

Praktik pembiayaan gadai dengan jaminan emas di Indonesia sendiri sudah diatur dalam fatwa DSN MUI nomor: 25/DSN-MUI/III/2002. Dengan dikeluarkanya fatwa tersebut transaksi pembiayaan gadai emas telah berkembang dan mulai dilirik masyarakat. Dengan kemudahan yang diberikan dan proses yang mudah bukan berarti produk gadai emas tidak memiliki risiko. Setiap pembiayaan yang dilakukan bank pasti mempunyai risiko, risiko tidak bisa dihindari tapi bisa dicegah dan dikendalikan, maka Lembaga keuangan ataupun bank harus mampu menjalankan manajemen risiko dengan baik. Dalam pembiayaan gadai emas risiko yang terjadi bisa berupa risiko yang disengaja maupun tidak disengaja, risiko yang muncul dari internal (bank) maupun eksternal (nasabah). Adiwarman A. Karim menjelaskan ketika menawarkan pembiayaan produk gadai emas risiko yang dialami adalah jika harga emas mengalami penurunan yang sangat drastis. Ketika harga emas anjlok tidak sedikit nasabah yang menunda menebus emas yang mereka miliki atau nasabah melakukan tunggakan yang menyebabkan pembiayaan macet, sehingga hal ini berpengaruh terhadap kondisi Lembaga keuangan tersebut akhirnya tidak sehat. ${ }^{2}$ Hal tersebut juga pernah terjadi di BSI KCP Krian, dimana terjadi kejadian nasabah yang melakukan tunggakan pembayaran ataupun mengalami pembiayaan macet yang disebabkan oleh penurunan harga emas. Selain kasus tersebut, tidak menutup kemungkinan terjadi resiko-resiko lain yang dialami oleh BSI KCP Krian khususnya pada produk gadai emas seperti adanya emas palsu yang dijadikan jaminan oleh nasabah.

Manajemen risiko kini menjadi bagian penting dari suatu bisnis yang tidak bisa dihindari, banyak perusahaan bangkrut sebab mengalami kerugian yang begitu besar. Hal ini tentu terjadi karena tidak bisa memperhitungkan risiko yang ada. Akan tetapi, bagi perusahaan yang telah berjalan serta memiliki bisnis usaha yang banyak, keputusan untuk menambahkan pengukuran risiko dalam sebuah pengambilan keputusan akan lebih baik dibandingkan dengan hanya menghitung potensi returnnya saja. Untuk itu bank Syariah harus menerapkan manajemen risiko dengan tujuan agar semua transaksi yang dijalankan oleh bank tidak menimbulkan kerugian terlebih mengganggu usaha dari bank tersebut. Dalam

\footnotetext{
1 Juliana, "Implementasi Manajemen Resiko Pembiayaan Gadai Emas Di Bank Syariah Mandiri KCP Poewali Mandar" (Parepare, 2020), http:// repository.iainpare.ac.id/2203/1/15.2300.002.pdf.

${ }^{2}$ Nadine Rizky Apriandany, "Manajemen Risiko Dalam Pembiayaan Gadai Emas (Studi Kasus BMT Maslahah Kantor Cabang Pabean Surabaya)" Vol. 7, no. No. 2 (2019): 1-12, https://jimfeb.ub.ac.id/index.php/jimfeb/article/view/5825/5123.
} 
pelaksanaanya manajemen risiko memiliki empat aspek yaitu identifikasi, pengukuran, pemantauan, dan pengendalian risiko yang muncul dari usaha bank. Dari penjelasan tersebut tujuan dari penelitian ini yaitu untuk menganalisis dan mengetahui implementasi manajemen risiko pada produk BSI gadai emas di BSI KCP Krian.

\section{Metode Penelitian}

Penelitian tentang implementasi manajemen risiko gadai emas di BSI KCP Krian merupakan penelitian kualitatif. Penelitian kualitatif yaitu salah satu jenis penelitian yang temuan-temuannya diperoleh dengan tidak melalui prosedur statistik atau bentuk hitungan lainya dan bertujuan untuk mengungkapkan secara holistic-kontekstual melalui pengumpulan data dari latar alami dengan memanfaatkan diri peneliti sebagai instrument kunci. ${ }^{3}$ Dalam penelitian ini, penulis memakai pendekatan induktif guna mencari kesimpulan secara global sesuai dengan fakta dan data yang terjadi di lapangan. Pendekatan induktif ini sangat bertumpu dengan fakta dan data yang terjadi di lapangan kemudian dihubungkan dengan teori yang relevan sehingga dapat ditarik kesimpulan yang tepat. Data dalam penelitian ini dikumpulkan dengan menggunakan teknik wawancara, dokumentasi, serta observasi. Penelitian ini difokuskan pada topik implementasi manajemen resiko gadai emas di BSI KCP Krian Sidoarjo. Peneliti akan melakukan kajian mendalam guna memberikan kerangka berpikir yang logis terkait implementasi manajemen resiko gadai emas di BSI KCP Krian.

\section{Literatur Review Bank Syariah}

Bank Syariah ialah bank yang secara operasionalnya tidak sama dengan bank konvensional. Dalam operasionalnya bank syariah berlandaskan pada prinsip syariah atau prinsip hukum islam yang diatur dalam fatwa Majelis Ulama Indonesia seperti prinsip keadilan dan keseimbangan ('adl wa tawazun), kemaslahatan (maslahah), universalisme (alamiyah), serta tidak mengandung gharar, maysir, riba, zalim dan obyek yang haram. Sementara itu, fungsi bank syariah sama halnya dengan bank konvensional yakni sebagai lembaga intermediasi yang menghimpun dana dari masyarakat kemudian menyalurkan kembali dana tersebut kepada masyarakat yang membutuhkan akan tetapi sesuai dengan prinsip syariah. ${ }^{4} \mathrm{Hal}$ yang dasar yang membedakan antara bank syariah dengan bank konvensional terdapat pada pengembalian serta pembagian keuntungan terhadap nasabah. ${ }^{5}$ Pada umumnya kegiatan perbankan terbagi menjadi tiga yakni produk penghimpunan dana (funding), produk penyaluran dana (landing) dan produk jasa (service). ${ }^{6}$

\section{Gadai Emas}

Gadai emas merupakan salah satu bentuk kegiatan penyaluran dana oleh pihak bank kepada nasabah yang membutuhkannya. Dalam Pengertian Bahasa Arab, gadai diartikan dengan Rahn yang secara etimologi memiliki makna menggadaikan, menangguhkan. Ditinjau dari istilah bahasa (lughah) kata rahn berarti tetap, kekal dan jaminan. ${ }^{7}$ Sedangkan emas merupakan logam mulia yang memiliki sifat likuiditas tinggi, artinya emas tahan akan inflasi

\footnotetext{
${ }^{3}$ Eko Sugiarto, Menyusun Proposal Penelitian Kualitatif: Skripsi Dan Tesis, pertama (Yogyakarta: Suaka Media, 2015).

${ }^{4}$ Rahmat Ilyas, "Manajemen Permodalan Bank Syariah," BISNIS : Jurnal Bisnis Dan Manajemen Islam 5, no. 2 (2017): 323-38, https://doi.org/10.21043/bisnis.v5i2.3017.

5 Agus Marimin, Abdul Haris Romdhoni, and Tira Nur Fitria, "Perkembangan Bank Syariah Di Indonesia," Jurnal Ilmiah Ekonomi Islam 1, no. 02 (2015): 75-87, https://doi.org/10.29040/jiei.v1i02.30.

${ }^{6}$ Muhammad Yazid and Aji Prasetyo, Ekonomi Syariah (Teori Dan Praktik Di Lembaga Kenangan Syariah) (Surabaya: IMTIYAZ, 2019).

${ }^{7}$ Putri Dona Balgis, “Gadai Emas Syariah: Evaluasi Dan Usulan Akad Sesuai Prinsip Syariah,” Jurnal Jurisprudence 7, no. 1 (2017): 87-96, https://doi.org/10.23917/jurisprudence.v7i1.4349.
} 
setiap tahunnya serta dapat diperjual belikan, digadaikan, dan memperoleh pencairan dana di lembaga keuangan bank maupun lembaga keuangan non-bank. Maka dari itu, gadai emas syariah adalah produk pembiayaan berupa pemberian dana kepada nasabah dalam bentuk pinjaman dengan menjadikan emas sebagai jaminan, dimana semua barang jaminan akan dikuasai serta disimpan oleh lembaga terkait di tempat penyimpanannya. Secara Pengertian dan praktik gadai emas terbagi menjadi dua yakni, gadai emas konvensional dan gadai emas syariah. Gadai emas konvensional dalam praktiknya menerapkan sistem bunga yang bersifat akumulatif berbeda dengan gadai syariah yang tidak menerapkannya. Gadai emas syariah dalam praktiknya menggunakan akad ijarah, ijarah merupakan akad pemindahan hak guna atas barang atau jasa berdasarkan upah sewa barang jaminan tanpa adanya pemindahan kepemilikan. ${ }^{8}$

Sebelum melakukan kegiatan pembiayaan gadai emas syariah yang bertujuan untuk memperoleh dana dalam waktu jangka pendek, maka yang harus diperhatikan adalah rukun gadai. Menurut penjelasan ulama, terdapat empat rukun Rahn yaitu shigat (lafal ijab dan qabul), orang yang berakad (al-rahin dan al-murtahin), harta yang dijadikan agunan (al marhun ), dan hutang (ar marhun bih). ${ }^{9}$ Dalam penerapan pembiayaan gadai emas di perbankan syariah tentu saja terdapat berbagai risiko yang muncul dari pembiayaan tersebut. Oleh karena itu, pihak bank syariah harus menjaga kualitas pembiayaan, karena pembiayaan merupakan sebagain besar aset dari bank syariah maka harus melaksanakan prinsip kehatihatian dalam pemberian pembiayaan gadai emas.

\section{Risiko}

Bank dan risiko merupakan dua variabel yang saling terikat dan tidak dapat dipisahkan. Dalam kegiatan operasional sehari-hari pihak bank tidak akan lepas terhadap risiko yang timbul dari kegiatannya. ${ }^{10}$ Risiko sendiri merupakan sesuatu yang mengarah pada ketidakpastian atas terjadinya suatu peristiwa selama selang waktu tertentu yang mana peristiwa tersebut menyebabkan suatu kerugian baik itu kerugian kecil dan kerugian besar yang berpengaruh pada kelangsungan hidup perusahaan. Didunia perbankan risiko adalah kejadian yang amat besar dan terjadi. Baik yang dapat diperkirakan dan diukur oleh perbankan maupun yang tidak dapat diperkirakan yang secara langsung berdampak negatif bagi pendapatan dan permodalan bank. ${ }^{11}$ Berpedoman pada ketentuan Bank Indonesia PBI No. 5/8/PBI/2003 dan pembaharuan No. 11/25/PBI2009 tentang penerapan Manajemen Risiko bagi Bank umum, ada delapan risiko yang harus dikelola bank. Kedelapan jenis risiko diantaranya adalah risiko kredit, risiko pasar, risiko operasional, risiko likuiditas, risiko kepatuhan, risiko hukum, risiko reputasi, dan risiko strategik. ${ }^{12}$

Banyaknya lembaga perbankan yang ada di Indonesia dengan struktur pasar, pangsa pasar, ukuran dan kompleksitas perjuangan bank yang berbeda beda. maka tidak ada satu sistem manajemen risiko universal yang Mengingat perbedaan syarat pasar, struktur, ukuran, dan kompleksitas perjuangan bank maka tidak ada satu sistem manajemen risiko yang universal dapat dipakai oleh semua Lembaga perbankan. Dengan demikian lembaga

\footnotetext{
${ }^{8}$ Iwan Setiawan, "Penerapan Gadai Emas Pada Bank Syariah Perspektif Hukum Ekonomi Islam," Al-Daulah: Jurnal Hukum Dan Perundangan Islam 6, no. 1 (2016): 188-213.

${ }^{9}$ Nasrun Haroen, Fiqih Muamalah (Jakarta: Gaya Media Pratama, 2000).

10 Rheza Pratama, "Penerapan Manajemen Risiko Pada Perbankan Syariah (Studi Kasus Pada Bank Muamalat \& Bank Syariah Mandiri Cabang Kota Ternate)," Jurnal Mitra Manajemen 2, no. 6 (2018): 597-609, https://doi.org/10.52160/ejmm.v2i6.162.

11 Riris Wandayanik, "Implementasi Manajemen Risiko Pembiayaan Murabahah Di Bank Bni Syariah Kantor Cabang Pembantu Mojokerto," EL-Qist 05, no. 47 (2015): 963-79.

12 Peraturan Bank Indonesia No: 5/8/PBI/2003, "Peraturan Bank Indonesia No: 5/8/PBI/2003 Tentang Penerapan Manajemen Risiko Bagi Bank Umum” (2003).
} 
perbankan memiliki strategi penanganan manajemen risiko sesuai dengan fungsi dan kebutuhan serta komplesitas bank.

\section{Manajemen Risiko}

Manajemen risiko merupakan serangkaian prosedur serta metode yang digunakan untuk mengidentifikasi, mengukur, memantau, dan mengendalikan risiko yang timbul dari kegiatan usaha bank. ${ }^{13}$ Tujuan adanya manajemen risiko yakni untuk menanggulangi suatu permasalahan sesuai dengan startegi yang digunakan dalam melaksanakan kegiatan suatu organisasi baik di masa lalu, masa sekarang, maupu masa depan. Dalam hal ini manajemen risiko perusahaan harus bersifat berkelanjutan dan dapat berkembang sesuai dengan kondisi yang dihadapi. Agar perusahaan dapat mencegah atau meminimalisir kerugian yang ditimbulkan oleh risiko yang terjadi terhadapnya.

Perusahaan atau organisasi dalam impelementasi manajemen risiko terdiri dari empat tahapan yakni: $:^{14}$

1. Identifikasi Risiko. Mekanisme analisis risiko perusahaan dilaksanakan dengan menganalisa seluruh sumber dan jenis risiko yang paling kurang dilakukan terhadap risiko dari produk dan aktivitas perusahaan serta memastikan bahwa risiko dari produk dan aktivitas baru sudah melalui proses manajemen risiko yang layak sebelum diperkenalkan atau dijalankan.

2. Pengukuran Risiko. Sistem pengukuran risiko perusahaan dipergunakan untuk mengukur eksposur risiko perusahaan sebagai acuan untuk melakukan pengendalian risiko dengan membuat kebijakannya.

3. Pemantauan Risiko. Perusahaan harus mempunyai sistem aturan dan tata kelola pemantauan yang melingkupi pengamatan terhadap besarnya eksposur risiko, toleransi risiko, kepatuhan limit internal, serta yang akan terjadi stress testing ataupun konsistensi pelakanaan menggunakan kebjikaan dan prosedur yang ditetapkan.

4. Pengendalian Risiko. Perusahan harus memiliki sistem pengendalian risiko yang memadai dan memumpuni dengan megacu pada keputusan dan mekanisme yang sudah ditetapkan. Proses pengendalian risiko yang dijalankan perusahaan harus diadaptasi dan diperbaharui dengan eksposur risiko maupun tingkat risiko yang akan diambil serta toleransi risiko.

Dari penerapan manajemen risiko yang baik akan bermanfaat pada perusahaan khususnya pada sektor perbankan. Dimana pihak perbankan akan memperoleh gambaran mengenai kemungkinan terjadinya kerugian bank di masa yang akan datang, meningkatkan metode dan proses pengambilan keputusan yang sistematis berdasarkan ketersediaan informasi, sebagai acuan yang lebih akurat atas kinerja bank, digunakan untuk mengevaluasi alat yang relativ kompleks atau risiko yang melekat pada aktivitas perbankan, serta menciptakan infrastruktur manajemen risiko yang kuat untuk meningkatkan daya saing bank. ${ }^{15}$ Oleh karena itu,implementasi manajemen risiko khususnya oleh perbankan syariah harus diterapkan secara maksimal sesuai dengan ketentuan yang mengaturnya.

\footnotetext{
13 Tahta Fikruddin and Fathul Mufid, "Strategi Penanganan Risiko Pembiayaan Murabahah Pada BMT Se Kabupaten Demak," Equilibrium 3, no. 2 (2015): 255-270.

14 Muhammad Farid and Wafiq Azizah, "Manajemen Risiko Dalam Perbankan Syariah," Mubasabatuna: Jurnal Akuntansi Dan Keuangan Islam 3, no. 2 (2021): 067-080.

15 Jureid, "Manajemen Risiko Bank Islam (Penanganan Pembiayaan Bermasalah Dalam Produk Pembiayaan Pada Pt. Bank Muamalat Cabang Pembantu Panyabungan)," Analytica Islamica 5, no. 1 (2016): 81-107.
} 
The Risk Management of Gold Pawn Product in

Bank Syariah Indonesia (BSI) Krian Branch

\section{Hasil dan Diskusi}

\section{Implementasi Manajemen Risiko Pada Produk Gadai Emas di BSI KCP Krian}

Perkembangan industri perbankan pada saat ini mengalami pertumbuhan yang sangat pesat dibandingkan dengan industri keuangan lainnya. Pertumbuhan ini bisa dilihat dengan munculnya berbagai jenis produk yang ditawakan serta semakin meningkatnya masyarakat yang memanfaatkan berbagai produk perbankan. Seiring dengan cepatnya laju pertumbuhan tersebut, maka risiko yang akan dihadapi oleh industri perbankan semakin besar. Risiko yang muncul seiring dengan pertumbuhan industri perbankan tidak boleh dibiarkan agar tidak memberikan dampak yang negatif bagi perusahaan. Salah satu bentuk penganan risiko yakni dengan melakukan manajemen risiko yang baik. manajemen risiko sendiri merupakan serangkaian prosedur ataupun tata cara yang digunakan untuk mengindentifikasi, mengukur, memantau, serta mengendalikan risiko yang ditimbulkan dari kegiatan bank. ${ }^{16}$ Penerapan manajemen risiko perbankan harus sesuai dengan prinsip kehati-hatian berdasarkan UndangUndang maupun peraturan yang mengaturnya. Tujuan dari manajemen risiko ialah menjaga supaya semua kegiatan bank tidak mengakibatkan kerugian yang melebihi batas kemampuan atau menganggu keberlangsungan usaha bank. Adapun proses manajemen risiko yang dilakukan pihak BSI KCP Krian dalam produk gadai emas terdiri dari empat tahap. Tahap yang pertama yaitu identifikasi risiko, identifikasi risiko adalah tindakan yang dilakukan untuk mengindentifikasi berbagai jenis risiko yang akan dihadapi oleh perusahaan. ${ }^{17}$ Proses identifikasi risiko dapat dimulai dengan mengamati berbagai potensi risiko baik yang terlihat maupun tidak terlihat, proses pengamatan tersebut bisa dilakukan dengan cara menggali atas sumber risiko sampai timbulnya kejadian yang tidak diinginkan oleh perusahaan.

Dalam proses identifikasi risiko yang dilakukan oleh pihak BSI KCP Krian pada produk gadai emas memfokuskan pada berbagai jenis risiko yakni, risiko operasional, risiko likuiditas, serta risiko pasar. Identifikasi risiko operasional pada gadai emas ditekankan pada keakuratan proses penaksiran dan kemanan penyimpanan emas. Emas yang dijadikan jaminan bisa dari logam mulia ataupun perhiasan, akan tetapi untuk jaminan emas berbentuk perhiasan minimal mempunyai kadar emas sebesar 16 karat. Manajemen bank khususnya staff yang menangani pembiayaan produk gadai emas harus sangat memperhatikan keakuratan proses penaksiran emas. Dikarenakan keakuratan penaksiran sangat berperan penting terhadap pemberian besarnya pembiayaan gadai emas yang akan diberikan kepada nasabah. Proses identifikasi selanjutnya yakni berkaitan dengan risiko likuiditas yang akan dihadapi oleh pihak bank. Risiko likuiditas ini ditekankan terkait gagal bayar atau macet yang dilakukan oleh nasabah pada saat proses pemberian pembiayaan gadai emas. Gagal bayar atau macet bisa terjadi karena keadaan makro ekonomi yang ada di masyarakat ataupun dari segi kemauan nasabah itu sendiri dalam proses pembayaran gadai emas. Dalam meminimalisir terjadinya keadaan gagal bayar bagi nasabah, pihak BSI KCP Krian senantiasa berinteraksi maupun memberikan sosialisasi kepada nasabah terkait dengan proses kewajiban pembayaran angsuran.

Kemudian terkait dengan identifikasi risiko pasar, BSI KCP Krian dalam hal ini menekankan pada identifikasi terkait dengan penurunan harga emas. Dikarenakan harga acuan jual atau beli emas bersifat fluktuatif. Oleh sebab itu pihak manajemen wajib menjalankan identifikasi risiko secara baik. Dikarenakan setiap proses identifikasi risiko dilakukan oleh pihak manajemen akan berkaitan dengan langkah yang akan diambil oleh bank

\footnotetext{
16 Sri Hayati, Manajemen Risiko Untuk Bank Perkreditan Rakyat Dan Lembaga Kenangan Mikro (Yogyakarta: CV. Andi Offset, 2017).

17 Rahmani Timorita Yulianti et al., "Studi Komparasi Penerapan Manajemen Risiko Produk Pembiayaan Di Lembaga Keuangan Mikro Syariah," Jurnal Syarikah: Jurnal Ekonomi Islam 4, no. 1 (2018): 59-71, https://doi.org/10.30997/jsei.v4i1.1060.
} 
dalam menghadapi berbagai risiko yang timbul dari pembiayaan produk gadai emas. Tahap kedua terkait dengan implementasi manajemen risiko produk BSI gadai emas oleh BSI KCP Krian yakni tahap pengukuran risiko. Pengukuran risiko merupakan proses terstruktur yang dilaksanakan oleh perusahaan dalam mengukur risiko yang dihadapi melalui kuantitas risiko yang sering terjadi. Pengukuran risiko digunakan sebagai acuan dari kerugian yang akan ditimbulkan oleh risiko yang terjadi pada perusahaan. ${ }^{18}$ Pengukuran risiko yang dilakukan khususnya pada kegiatan gadai emas akan mencerminkan seberapa besar ataupun banyak risiko yang ditimbulkan oleh kegiatan tersebut yang dapat mempengaruhi kegiatan gadai pada masa sekarang dan selanjutnya.Setelah melakukan proses identifikasi risiko terhadap produk gadai emas, proses selanjutnya BSI KCP Krian yakni pengukuran risiko. Untuk pengukuran risiko pihak BSI KCP Krian melakukan penilaian risiko yang sering terjadi pada pemberian produk gadai emas. Dari penilain atas risiko produk gadai emas tersebut akan diketahui risiko apa saja yang sering terjadi dalam pemberian produk gadai emas. Pertama risiko yang sering terjadi yakni mengenai risiko likuiditas terkait dengan gagal bayar dan macet terutama pada saat pandemi covid-19 kali ini. Berdasarkan keterangan dari Bapak Firman selaku officer produk gadai dan cicil emas menyatakan bahwasanya kebanyakan nasabah yang melakukan pembiayaan produk gadai yakni para wiraswasta yang digunakan untuk modal kerja dalam rangka pengembangan usahanya. Melalui proses screening awal pada produk gadai emas diketahui bahwasanya dana yang diberikan digunakan $80 \%$ untuk kegiatan produktif serta $20 \%$ untuk konsumtif. Risiko gagal bayar bayar atau macet paling sering terjadi dalam pemberian produk pembiayaan di sektor perbankan khusunya pada produk gadai emas.

Risiko kedua yang sering terjadi dalam pembiayaan produk gadai emas di BSI KCP Krian yakni risiko operasional yang meliputi risiko keakrutan penaksiran dan penyimpanan emas. Salah satu aspek yang amat penting pada pemberian pembiayaan gadai emas yakni aspek collateral berupa emas yang dijaminkan. Oleh karena itu dalam proses penaksiran emas harus dilakukan secara teliti agar tidak timbul beragam risiko kedepannya. Untuk kasus terkait risiko operasional BSI KCP Krian pernah terjadi kesalahan dalam proses penaksiran emas yang menimbulkan kerugian pada pihak bank. Namun, kerugian yang ditimbulkan tidak terlalu berdampak parah, dikarenakan pihak bank akan segera melakukan tindakan yakni penaksiran ulang apabila diketahui adanya ketidakakuratan terhadap penaksiran emas. Akan tetapi apabila seringkali terjadi kesalahan penaksiran akan berdampak buruk terhadap citra bank atau kepercayaan nasabah pada pihak BSI KCP Krian. Risiko pasar terkait penurunan emas menempati posisi terakhir yang diperhatikan oleh pihak BSI KCP Krian. Dalam kasus penurunan harga emas seringkali terjadi pada BSI KCP Krian. Akan tetapi risiko yang ditimbulkan dari penurunan emas tidak menimbulkan dampak yang besar bagi pihak BSI KCP Krian. Dikarenakan pihak BSI KCP Krian memiliki kebijakan tersendiri untuk mengatasi terjadinya penurunan harga emas kedepannya. Sehingga dalam hal ini pihak BSI KCP Krian dianggap dapat mengatasi terhadap risiko pasar terkait dengan penurunan harga emas. Di lain sisi untuk mencegah ketidaksesuian harga jual maupun beli pihak BSI KCP Krian setiap harinya akan selalu memperbaharui harga emas sesuai dengan harga jual atau beli yang berlaku pada waktu itu.

Pada tahap ketiga setelah proses pengukuran risiko pihak BSI KCP Krian melakukan proses pemantauan risiko. Pemantauan risiko adalah sebuah proses evaluasi terhadap tingkat risiko pada suatu perusahaan serta pelaksanaan manajemen risiko. Selain digunakan untuk mengevaluasi risiko serta pelaksanaan manajemen risiko, pemantauan risiko ditujukan untuk senantiasa mengindentifikasi serta mengelola berbagai risiko yang baru. Temuan yang

18 Yunita Sari, Syaiful Muhyidin, and Fachrudin Fiqri Affandy, "Manajemen Risiko Gadai Emas Pada Pt.Pegadaian Syariah Jayapura," OIKONOMIKA : Jurnal Kajian Ekonomi Dan Keuangan Syariah 1, no. 2 (2020): 117, https://doi.org/10.53491/oikonomika.v1i2.69. 
dihasilkan saat pemantauan risiko tersebut akan dijadikan sebagai informasi yang akurat bagi pihak perusahaan guna untuk penentuan strategi yang akan dilakukan. ${ }^{19}$

Rangka pemantauan nasabah pihak BSI KCP Krian sudah memiki suatu sistem yang secara otomatis yang akan memunculkan seluruh kategori nasabah. Dalam sistem tersebut pihak BSI KCP Krian dapat mengetahui kategori nasabah baik yang lancar ataupun bermasalah. Apabila ada nasabah yang termasuk dalam kategori pembiayaan bermasalah akan ditindak dengan prosedur yang telah ditetapkan. Dari sistem tersebut juga digunakan sebagai sarana informasi terkait tanggal jatuh tempo nasabah dalam pembayaran gadai emas. Pihak staff gadai emas H-1 akan menghubungi nasabah melalui pesan singkat ataupun telefon. Pada lain sisi dalam rangka pemantauan nasabah pihak BSI KCP Krian menjalin komunikasi yang baik dengan nasabahnya. Sehingga dengan adanya komunikasi yang baik dengan nasabah dapat meminimalisir timbulnya gagar bayar atau macet. Jikalau nasabah ada kendala terkait dengan pembayaran gadai emas dianjurkan oleh pihak BSI KCP Krian agar menyampaikan ke pihak bank agar nantinya dapat di carikan solusi secara bersama-sama.

Tahap terkahir dalam implementasi manajemen risiko pada produk BSI gadai emas yakni pengendalian risiko. Dalam rangka pengendalian risiko pihak BSI KCP Krian berfokus pada dua cara yakni menghindari risiko serta mengendalikan kerugian. Tindakan menghindari risiko difokuskan sebelum terjadinya pemberian pembiayaan gadai emas. Pada saat sebelum pemberian pembiayaan gadai emas akan dilakukan analisis yang sangat ketat agar menghindari risiko yang mungkin akan terjadi. Khususnya saat penaksiran emas dilaksanakan secara ketat dan teliti baik keaslian, ukuran serta dokumen kepemilikan emas nasabah oleh pihak BSI KCP Krian. Sehingga sebelum disetujuinya pembiayaan gadai emas pihak BSI KCP Krian akan melakukan berbagai screening yang ketat guna untuk menghindari risiko yang akan terjadi. Untuk meminimalisir atau mencegah banyaknya nasabah yang mengalami gagal bayar atau macet pihak BSI KCP Krian melakukan proses screening awal pada waktu pengajuan ataupun saat dilakukannya akad pembiayaan produk gadai emas. Metode yang digunakan oleh BSI KCP Krian dalam screening awal pengajuan pembiayaan gadai emas yakni dengan menerapkan prinsip 5C $+1 \mathrm{~S}$. Penerapan prinsip 5C $+1 \mathrm{~S}$ lebih ditekankan pada penilaian atas collateral, capacity, dan character. Untuk penerapan prinsip $5 \mathrm{C}+1 \mathrm{~S}$ dalam pemberian pembiayaan produk gadai emas tidak sedetail seperti pemberian produk lainnya seperti produk pembiayaan konsumtif ataupun modal kerja. Dengan diterapkannya prinsip penilaian tersebut ditujukan sebagai upaya untuk mencegah timbulnya pembiayaan macet.

Selanjutnya pengendalian risiko dengan cara mengendalikan atau meminimalisir risiko kerugian bagi pihak BSI KCP Krian. Mengendalikan kerugian biasanya dilakukan setelah pemberian pembiayaan gadai emas. Dimana risiko yang sering terjadi yakni risiko likuiditas dan risiko pasar. Sehingga pihak BSI KCP Krian harus mempunyai strategi untuk meminimalisir kerugian yang terjadi. Khususnya risiko yang sering terjadi mengenai gagal bayar atau macet oleh nasabah, dalam hal ini pihak BSI memiliki strategi yakni dengan cara melakukan strukturisasi pembiayaan gadai emas. Pemberian strukturisasi pembiayaan yang diberikan oleh pihak BSI KCP Krian tidak berlaku kepada semua nasabah, akan tetapi berlaku terhadap nasabah yang memiliki itikad baik untuk melunasi tangunggan pembayaran serta memiliki kemampuan memenuhi kewajiban setelah direstrukturisasi. Dengan pemberian strukturisasi pembiayaan bagi nasabah ini akan meminimalisir kerugian yang akan ditimbulkan dari pembiayaan tersebut. Cara kedua yakni dengan cara melakukan penjualan atau lelang atas barang jaminan sebagai langkah terakhir bagi nasabah yang kesulitan untuk membayar kewajibannya. Langkah ini digunakan untuk menutupi kerugian yang ditimbulkan serta sebagai tindakan pihak bank dalam membantu nasabah yang tidak sanggup untuk

19 Syathir Sofyan, "Analisis Penerapan Manajemen Risiko Pembiayaan Pada Lembaga Pembiayaan Syariah," Bilancia: Jurnal Studi Ilmu Syariah Dan Hukum 11, no. 2 (2017): 359-90, https://doi.org/10.24239/blc.v11i2.310. 
melunasi hutangnya saat jatuh tempo. Proses pelelangan ini terjadi apabila pihak nasabah tidak sanggup atau memiliki itikad baik untuk melunasi hutangnya. Akan tetapi terkadang ada nasabah yang mengajukan kepada pihak bank untuk melakukan pelelangan terhadap jaminannya. Dikarenakan nasabah merasa tidak mampu melunasi hutangnya saat jatuh tempo sehingga pihak bank akan melakukan pelelangan atas jaminannya. Jikalau hasil dari pelelangan terdapat sisa atau kelebihan maka pihak bank mengembalikannya kepada nasabah.

\section{Mitigasi Risiko Pada Produk Gadai Emas}

Berdasarkan hasil observasi dan wawancara pada informan diketahui bahwasanya selain mengimplementasikan manajemen risiko pihak BSI KCP Krian juga menyiapkan mitigasi risiko terhadap produk gadai emas. Tindakan mitigasi risiko ditujukan guna untuk meminimalisir ataupun mencegah risiko yang menimbulkan kerugian bagi pihak bank. ${ }^{20}$ Kebijakan mitigasi risiko diambil setelah proses analisis yang mendalam terhadap berbagai risiko yang terjadi agar mitigasi risiko yang diterapkan bisa akurat. Dalam hal ini pihak BSI KCP Krian memiliki berbagai strategi dalam meminimalisir atau mencegah risiko yang kemungkinan terjadi pada produk BSI gadai emas. Dalam menghadapi risiko keakuratan penaksiran emas pihak BSI KCP Krian memiliki kebijakan mitigasi risiko yakni dengan cara pihak bank akan melakukan beberapa prosedur pengujian baik untuk membuktikan keaslian emas sebagai barang jaminan ataupun besarnya karatase. Dalam melakukan proses penaksiran ada beberapa tahapan yaitu uji fisik dengan melakukan pengamatan kondisi serta warna emas, uji kimia dilakukan dengan cara perhiasan atau emas digosokkan di atas batu uji kemudian ditetesi dengan cairan HCL, uji berat pada emas dengan cara ditimbang. Apabila setalah proses uji tersebut masih diragukan oleh pihak bank, maka bank akan melakukan cara lain yakni dengan mengikir emas akan tetapi proses tersebut meminta ijin kepada nasabah terlebih dahulu.

Sementara itu, jika di kemudian hari teryata emas yang digunakan sebagai barang jaminan tidak asli atau palsu ataupun bukan milik pribadi, maka nasabah wajib menanggung segala risiko dan mengganti seluruh kerugian yang ditimbulkan. Disisi lain pihak BSI KCP Krian selalu melakukan pelatihan tentang keakrutan dalam penaksiran emas khususnya kepada staff produk gadai emas. Mitigasi risiko selanjutnya yakni terkait dengan risiko penyimpanan emas, dimana BSI KCP Krian memiliki ruang brankas yang dikenal dengan nama khasanah untuk menyimpan barang jaminan nasabah. Yang mana brankas tersebut dilengkapi dengan fasilitas anti api serta di dalam ruang brankas terdapat CCTV. Emas jaminan tersebut akan disimpan berdasarkan golongan emas dan nomer urut. Sebelum dimasukan ke brankas, emas akan dipacking menjadi satu dengan dokumen pendukungnya agar tetap aman dan tidak berserakan. Disisi lain emas tersebut akan diasuransikan oleh pihak BSI KCP Krian guna untuk memitigasi risiko atas kehilangan atau tindakan pencurian. Apabila emas tersebut hilang maka akan diganti oleh pihak bank dengan nominal harga jual sesuai dengan nilai taksiran di awal saat akad berlangsung.

Berdasarkan pernyataan dari Bapak Fajar selaku marketing produk gadai dan cicil emas mengatakan bahwasanya mitigasi risiko terkait dengan gagal bayar BSI KCP Krian cenderung ditekankan kepada FTV (Financing To V alue). Untuk FTV pemberian pinjaman gadai emas BSI KCP Krian menetapkan sebesar $80 \%$ dari nilai taksiran barang jaminan. Dengan penetapan FTV ini ditujukan untuk meminimalisir kerugian yang timbul akibat gagal bayar atau macet oleh nasabah. Pihak BSI KCP Krian akan mengirim pesan maupun telpon kepada nasabah $\mathrm{H}-1$ sebelum jatuh tempo pembayaran. Jikalau nasabah dalam tempo waktu $\mathrm{H}+3$ tidak memberikan konfirmasi kepada pihak bank, maka pihak bank akan menelfon nasabah

20 Atiqi Chollisni Nasution and Abdullah Hafidzy, "Analisis Manajemen Risiko Pada Pembiayaan Murabahah Di BPRS Berkah Ramadhan,” EL-UJRAH: Journal Of Islamic Banking and Finance 01, no. 01 (2021): 25-38. 
menanyakan terkait pembayaran gadai emas. Pihak bank akan menanyakan penyebab gagal bayar kepada nasabah dalam proses pembayaran. Apabila nasabah mengalami penurunan kemampuan dan memiliki itikad baik dalam memenuhi kewajibannya, maka pihak bank akan memberikan strukturisasi pembiayaan bagi nasabah. Sebaliknya, jika nasabah tidak memiliki itikad baik dan pasrah maka pihak bank pada $\mathrm{H}+7$ akan melakukan pelelangan barang jaminannya. Guna untuk menutupi kerugian yang timbul akibat pembiyaan gadai emas. Akan tetapi BSI KCP Krian dalam meyelesaikan gagal bayar atau macet selalu mengutamakan asas kekeluargaan dengan memberikan pengertian kepada nasabah secara halus dan mencari solusi bersama-sama.

Mitigasi risiko penerunan harga emas sama halnya dengan gagal bayar atau macet yakni menekankan pada aspek FTV (Financing to Value). Agar meminimalisir kerugian akibat fluktuasi harga emas pihak BSI KCP Krian memberikan pembiayaan $80 \%$ dari nilai FTV taksiran barang jaminan. Akan tetapi pada situasi pandemi ini dalam pemberian gadai emas tidak secara utuh memberikan $80 \%$ dari taksiran barang jaminan. Akan tetapi untuk meminimalisir penurunan dan kenaikan harga pihak bank memberikan pembiayaan gadai emas sekitar kurang dari 80\% daari nilai taksiran barang jaminan. Sebagai contoh kasus pada tahun 2020 harga emas sangat berflukatif. Dimana harga emas mengalami kenaikan yang cukup tinggi namun juga tiba-tiba mengalami penurunan cukup drastis. Maka pihak BSI KCP Krian memitigasi risiko dengan cara menyampaikan diawal saat akad kepada nasabah jikalau nanti harga emas terjadi penurunan drastis maka nasabah harus mengurangi besarnya nilai pokok pembiayaan. Pengembalian pokok pembayaran nasabah kepada pihak bank bisa secara tunai maupun dicicil sesuai dengan kemampuan nasabah. Kemudian juga dengan cara memberikan strukturisasi kepada nasabah terkait dengan proses penyesuaian pembayaran akibat terjadinya penurunan harga emas. Risiko penurunan harga emas untuk selama ini sangat mampu dikendalikan oleh pihak BSI KCP Krian. Dikarenakan harga produk emas di pasar sangat stabil sehingga masih bisa diantisipasi oleh pihak bank.

\section{Hambatan dalam Implementasi Manajemen Risiko pada Produk Gadai Emas}

Dalam proses implementasi manajemen risiko yang dilaksanakan oleh pihak BSI KCP Krian tentu saja terdapat berbagai hambatan. Hambatan dalam proses implementasi manajemen risiko tersebut dapat berasal dari internal maupun eksternal bank. Hambatan internal merupakan hambatan yang timbul dari dalam bank. Misalnya hambatan internal yang terjadi yaitu pihak bank salah melakukan penaksiran maupun menginput data gadai emas. Hal ini terjadi dikarenakan pihak staff berfokus pada target pertumbuhan produk pembiayaan gadai emas yang telah ditetapkan oleh pihak manajemen bank. Dengan adanya target pertumbuhan setiap bulan yang harus tercapai seringkali manajemen risiko yang ditetapkan sebelumnya tidak dilaksanakan dengan baik sesuai prosedur yang ada. Maka dengan hal ini akan menyebabkan timbulnya kesalahan meskipun tidak berdampak besar terhadap kesehatan bank. Sementara itu upaya yang dilakukan oleh BSI KCP Krian untuk mengatasi hambatan internal yakni dengan cara melakukan pengecekan kembali jaminan tersebut. Pengecekan tersebut akan dilakukan oleh staff produk pembiayaan gadai emas melalui sebuah aplikasi yang bernama PWG Moon. Pihak staff akan melakukan pengecekan kembali atas barang jaminan nasabah di sistem ini. PWG Moon ini ditujukan untuk meminimalisir terjadinya kesalahan dalam hal taksiran maupun input data jaminan nasabah. Melalui sistem ini akan diketahui apabila terdapat kesalahan pihak internal dalam melakukan taksiran atau proses menginput data. Kelebihan dari sistem PWG Moon ini yaitu data yang ditampilkan sesuai dengan jaminan yang diberikan oleh nasabah dan tidak ada yang bisa melakukan manipulasi data jaminan. Di lain sisi pihak BSI Krian juga senantiasa memberikan pelatihan kepada pegawainya agar dapat menjalankan prosedur pelayanan yang baik. 
Selanjutnya hambatan eksternal merupakan hambatan yang timbul dari luar bank. Hambatan eksternal dalam penerapan manajemen risiko oleh BSI KCP Krian seringkali ditimbulkan oleh pihak nasabah. Dimana terkadang dalam proses pembiayaan gadai emas terdapat nasabah yang kurang koorperatif dengan pihak bank. Khususnya nasabah yang mengalami pembiayaan macet terkadang mereka tidak mengatakan secara jujur kepada pihak bank mengenai penyebab nasabah mengalami kesulitan memenuhi kewajibannya. Hambatan eksternal selanjutnya yakni terdapat nasabah saat pengajuan pembiayaan gadai emas terdapat itikad untuk menyuap pegawai pihak bank agar diberikan pembiayaan yang mereka inginkan. Padahal sudah diketahui oleh nasabah bahwasanya pembiayaan yang akan diberikan sesuai dengan nilai taksiran emas yang dijaminkan. BSI KCP Krian dalam upaya mengatasi hambatan eksternal yang terjadi lebih mengutamakan kepada asas kekeluargaan. Terkait dengan pihak yang kurang koorperatif dalam proses pembiayaan, pihak bank akan memberikan penjelasan secara halus kepada nasabah agar bisa lebih bersifat koorperatif. Dari sifat koorperatif tersebut antara pihak bank dan nasabah dalam proses pembiayaan tidak ada yang dirugikan. Apabila nasabah setelah diberikan penjelasan tetap tidak berubah maka nasabah yang mengalami gagal bayar akan diselesaikan dengan prosedur penyelesaian pembiayaan yang berlaku.

Selanjutnya untuk mengatasi nasabah yang mempunyai i'tikad untuk melakukan penyuapan, pihak BSI KCP Krian memiliki dua macam jenis cara. Tentu saja dalam hal ini pihak BSI KCP Krian dengan tegas akan menolak segala macam suap atau pemberian barang apapun oleh nasabah saat kegiatan operasional bank. Cara pertama yang dilakukan oleh pihak BSI KCP Krian yakni dengan cara memberikan penjelasan kepada nasabah bahwasanya pihak bank menolak secara tegas segala jenis penyuapan. Pihak bank akan memberikan pembiayaan kepada nasabah apabila memenuhi prosedur yang telah ditetapkan oleh pihak bank. Kemudian untuk besarnya pembiayaan yang diberikan kepada nasabah sesuai dengan nilai taksiran barang jaminan. Apabila nasabah sudah diberikan penjelasan namun tetap melakukan penyuapan maka pihak bank akan memakai cara kedua. Adapun cara kedua yakni pihak bank tidak bisa memberikan pembiayaan yang diajukan oleh nasabah. Dikarenakan pihak bank dalam menjalankan proses pemberian gadai emas harus mematuhi prosedur yang berlaku. Pihak bank akan memberikan pembiayaan apabila nasabah mematuhi prosedur yang telah ditetapkan oleh pihak bank.

\section{Kesimpulan}

Manajemen risiko merupakan serangkaian prosedur serta metode yang digunakan untuk mengidentifikasi, mengukur, memantau, dan mengendalikan risiko yang timbul dari suatu usaha. Berdasarkan hasil penelitian tersebut diketahui bahwasanya dalam pembiayaan BSI gadai emas menimbulkan berbagai macam risiko yakni risiko operasional, risiko likuiditas, serta risiko pasar. Oleh karena itu, pihak BSI KCP Krian dalam meminimalisir risiko yang timbul dari pembiayaan BSI gadai emas mengimplementasikan manajemen risiko. BSI KCP krian dalam menerapkan manajemen risiko terdapat empat proses yakni identifikasi risiko, pengukuran risiko, pemantuan risiko, dan pengendalian risiko. Kemudian dalam penelitian ini menunjukkan bahwa pihak BSI KCP Krian selain menerapkan manajemen risiko juga telah menyiapkan mitigasi risiko terhadap produk BSI gadai emas. Mitigasi risiko ini ditujukan untuk meminimalisir ataupun mencegah risiko yang akan menimbulkan kerugian terhadap pihak BSI KCP Krian. Mitigasi risiko yang diterapkan oleh BSI KCP Krian meliputi mitigasi risiko keakuratan penaksiran emas, mitigasi risiko penyimpanan emas, mitigasi risiko gagal bayar atau macet, serta mitigasi risiko terkait penurunan harga emas. Hasil penelitian ini juga diketahui bahwasanya dalam penerapan manajemen risiko terdapat dua hambatan yakni hambatan internal dan eksternal. Namun, hambatan tersebut dapat 
The Risk Management of Gold Pawn Product in

Bank Syariah Indonesia (BSI) Krian Branch

ditangani secara baik oleh pihak BSI KCP Krian baik dengan cara kekeluargaan ataupun tindakan tegas terhadap nasabah.

\section{Saran}

Berdasarkan hasil pembahasan dalam penelitian tersebut, maka penulis dapat memberikan saran sebagai berikut. Bagi akademisi, hasil penelitian ini dapat memberikan kontribusi pada ilmu manajemen keuangan serta perbankan syariah. Selain itu, penelitian ini kedepannya dapat dijadikan sebagai referensi penelitian-penelitian yang relevan. Bagi perbankan syariah khususnya BSI KCP Krian, hasil penelitian ini dapat memberikan informasi ataupun referensi bagi pihak perbankan terkait dalam mengelola serta menerapkan manajemen risiko pada produk perbankan syariah. Bagi nasabah perbankan syariah khususnya nasabah BSI KCP Krian, bahwasanya nasabah harus mematuhi prosedur yang ditetapkan oleh pihak bank dalam pemberian produknya. Yang mana antara nasabah dan pihak bank saling diuntungkan dan tidak ada salah satu pihak yang dirugikan.

\section{Daftar Pustaka}

Apriandany, Nadine Rizky. "Manajemen Risiko Dalam Pembiayaan Gadai Emas (Studi Kasus BMT Maslahah Kantor Cabang Pabean Surabaya)" Vol. 7, no. No. 2 (2019): 112. https://jimfeb.ub.ac.id/index.php/jimfeb/article/view/5825/5123.

Balgis, Putri Dona. "Gadai Emas Syariah: Evaluasi Dan Usulan Akad Sesuai Prinsip Syariah." Jurnal Jurisprudence 7, no. 1 (2017): 87-96. https://doi.org/10.23917/jurisprudence.v7i1.4349.

Farid, Muhammad, and Wafiq Azizah. "Manajemen Risiko Dalam Perbankan Syariah." Mubasabatuna: Jurnal Akuntansi Dan Kenangan Islam 3, no. 2 (2021): 067-080.

Fikruddin, Tahta, and Fathul Mufid. "Strategi Penanganan Risiko Pembiayaan Murabahah Pada BMT Se Kabupaten Demak.” Equilibrium 3, no. 2 (2015): 255-270.

Haroen, Nasrun. Fiqih Muamalah. Jakarta: Gaya Media Pratama, 2000.

Hayati, Sri. Manajemen Risiko Untuk Bank Perkreditan Rakyat Dan Lembaga Kenangan Mikro. Yogyakarta: CV. Andi Offset, 2017.

Ilyas, Rahmat. "Manajemen Permodalan Bank Syariah." BISNIS : Jurnal Bisnis Dan Manajemen Islam 5, no. 2 (2017): 323-38. https://doi.org/10.21043/bisnis.v5i2.3017.

Juliana. "Implementasi Manajemen Resiko Pembiayaan Gadai Emas Di Bank Syariah Mandiri KCP Poewali Mandar.” 2020. http:// repository.iainpare.ac.id/2203/1/15.2300.002.pdf.

Jureid. "Manajemen Risiko Bank Islam (Penanganan Pembiayaan Bermasalah Dalam Produk Pembiayaan Pada Pt. Bank Muamalat Cabang Pembantu Panyabungan)." Analytica Islamica 5, no. 1 (2016): 81-107.

Marimin, Agus, Abdul Haris Romdhoni, and Tira Nur Fitria. "Perkembangan Bank Syariah Di Indonesia." Jurnal Ilmiah Ekonomi Islam 1, no. 02 (2015): 75-87. https://doi.org/10.29040/jiei.v1i02.30.

Nasution, Atiqi Chollisni, and Abdullah Hafidzy. "Analisis Manajemen Risiko Pada Pembiayaan Murabahah Di BPRS Berkah Ramadhan.” EL-UJRAH: Journal Of Islamic Banking and Finance 01, no. 01 (2021): 25-38.

Peraturan Bank Indonesia No: 5/8/PBI/2003. Peraturan Bank Indonesia No: 5/8/PBI/2003 Tentang Penerapan Manajemen Risiko Bagi Bank Umum (2003).

Pratama, Rheza. "Penerapan Manajemen Risiko Pada Perbankan Syariah (Studi Kasus Pada Bank Muamalat \& Bank Syariah Mandiri Cabang Kota Ternate)." Jurnal Mitra Manajemen 2, no. 6 (2018): 597-609. https://doi.org/10.52160/ejmm.v2i6.162. 
Sari, Yunita, Syaiful Muhyidin, and Fachrudin Fiqri Affandy. "Manajemen Risiko Gadai Emas Pada Pt.Pegadaian Syariah Jayapura." OIKONOMIKA : Jurnal Kajian Ekonomi Dan Keuangan Syariah 1, no. 2 (2020): 1-17. https://doi.org/10.53491/oikonomika.v1i2.69.

Setiawan, Iwan. "Penerapan Gadai Emas Pada Bank Syariah Perspektif Hukum Ekonomi Islam." Al-Daulab: Jurnal Hukum Dan Perundangan Islam 6, no. 1 (2016): 188-213.

Sofyan, Syathir. "Analisis Penerapan Manajemen Risiko Pembiayaan Pada Lembaga Pembiayaan Syariah.” Bilancia: Jurnal Studi Ilmu Syariab Dan Hukum 11, no. 2 (2017): 35990. https://doi.org/10.24239/blc.v11i2.310.

Sugiarto, Eko. Menyusun Proposal Penelitian Kualitatif: Skripsi Dan Tesis. Pertama. Yogyakarta: Suaka Media, 2015.

Wandayanik, Riris. "Implementasi Manajemen Risiko Pembiayaan Murabahah Di Bank Bni Syariah Kantor Cabang Pembantu Mojokerto.” EL-Qist 05, no. 47 (2015): 963-79.

Yazid, Muhammad, and Aji Prasetyo. Ekonomi Syariah (Teori Dan Praktik Di Lembaga Kenangan Syariah). Surabaya: IMTIYAZ, 2019.

Yulianti, Rahmani Timorita, Abiyajid Bustami, Nur Atiqoh, and Rati Anjellah. "Studi Komparasi Penerapan Manajemen Risiko Produk Pembiayaan Di Lembaga Keuangan Mikro Syariah." Jurnal Syarikah: Jurnal Ekonomi Islam 4, no. 1 (2018): 59-71. https://doi.org/10.30997/jsei.v4i1.1060. 